https://helda.helsinki.fi

\title{
Virome of US bovine calf serum
}

\section{Sadeghi, Mohammadreza}

2017-03

Sadeghi , M , Kapusinszky , B , Yugo , D M , Phan , T G, Deng , X , Kanevsky , I , Opriessnig , T , Woolums , A R, Hurley , D J , Meng , X-J \& Delwart , E 2017 , ' Virome of US bovine calf serum ' , Biologicals , vol. 46 , pp. 64-67 . https://doi.org/10.1016/j.biologicals.2016.12.009

http://hdl.handle.net/10138/236701

https://doi.org/10.1016/j.biologicals.2016.12.009

publishedVersion

Downloaded from Helda, University of Helsinki institutional repository.

This is an electronic reprint of the original article.

This reprint may differ from the original in pagination and typographic detail.

Please cite the original version. 


\title{
Virome of US bovine calf serum
}

\author{
Mohammadreza Sadeghi a, b, c, Beatrix Kapusinszky ${ }^{\text {a, b }}$, Danielle M. Yugo ${ }^{\text {d }}$, \\ Tung Gia Phan ${ }^{\mathrm{a}, \mathrm{b}}$, Xutao Deng ${ }^{\mathrm{a}, \mathrm{b}}$, Isis Kanevsky ${ }^{\mathrm{e}}$, Tanja Opriessnig ${ }^{\mathrm{f}}$, \\ Amelia R. Woolums ${ }^{\mathrm{g}}$, David J. Hurley ${ }^{\mathrm{h}}$, Xiang-Jin Meng ${ }^{\mathrm{d}}$, Eric Delwart ${ }^{\mathrm{a}, \mathrm{b},{ }^{*}}$ \\ a Blood Systems Research Institute, San Francisco, CA, USA \\ ${ }^{\mathrm{b}}$ Department of Laboratory Medicine, University of California San Francisco, San Francisco, CA, USA \\ ${ }^{\mathrm{c}}$ Department of Virology, University of Helsinki, Finland \\ d Department of Biomedical Sciences and Pathobiology, College of Veterinary Medicine, Virginia Polytechnic Institute and State University, Blacksburg, VA, \\ USA \\ e Department of Dairy Science, College of Agriculture and Life Sciences, Virginia Polytechnic Institute and State University, Blacksburg, VA, USA \\ ${ }^{\mathrm{f}}$ The Roslin Institute and Royal (Dick) School of Veterinary Studies, University of Edinburgh, Midlothian, Scotland, UK \\ ${ }^{g}$ Department of Pathobiology and Population Medicine, College of Veterinary Medicine, Mississippi State University, MS, USA \\ h Department of Population Health, College of Veterinary Medicine, University of Georgia, Athens, GA, USA
}

\section{A R T I C L E I N F O}

\section{Article history:}

Received 27 October 2016

Received in revised form

2 December 2016

Accepted 29 December 2016

Available online 15 January 2017

\section{Keywords:}

Metagenomics

Parvovirus

Bosavirus

Cell culture

\begin{abstract}
A B S T R A C T
Using viral metagenomics we analyzed four bovine serum pools assembled from 715 calves in the United States. Two parvoviruses, bovine parvovirus 2 (BPV2) and a previously uncharacterized parvovirus designated as bosavirus (BosaV), were detected in 3 and 4 pools respectively and their complete coding sequences generated. Based on NS1 protein identity, bosavirus qualifies as a member of a new species in the copiparvovirus genus. Also detected were low number of reads matching ungulate tetraparvovirus 2 , bovine hepacivirus, and several papillomaviruses. This study further characterizes the diversity of viruses in calf serum with the potential to infect fetuses and through fetal bovine serum contaminate cell cultures.
\end{abstract}

๑ 2017 International Alliance for Biological Standardization. Published by Elsevier Ltd. All rights reserved.

\section{Introduction}

Fetal bovine serum is a potential source of viral contamination for cell cultures used in the production of biological products for human or animal use $[1,3,6,10,15-17,20]$ and is therefore routinely subjected to a range of virus-specific tests to ensure an absence of viral contaminations. While regulations list specific viruses whose absence must be confirmed, such as bovine viral diarrhea virus 1 and 2 and others, bovine viruses of concern beyond that list have been identified [15]. Viral removal through filtration or inactivation methods may be used to reduce the risk of viral contamination; however, small non-enveloped viruses with ssDNA genomes, such as parvoviruses, are less susceptible to such measures. Using an unbiased metagenomics approach we characterized viral sequences present in pools of bovine serum samples collected from

\footnotetext{
* Corresponding author. Blood Systems Research Institute, 270 Masonic Ave., San Francisco, CA, 94118, USA.

E-mail address: delwarte@medicine.ucsf.edu (E. Delwart).
}

calves in the US. The ability of these parvoviruses to contaminate fetal bovine serum remains to be determined.

\section{Materials and methods}

Four bovine sera pools collected from different areas of the United States were analyzed (Table 1). These samples were collected as part of a hepatitis $\mathrm{E}$ virus seroepidemiological study. The 25 calves in GA1 group and 90 calves in GA2 were sampled at $5-6$ time points. The 375 calves in IA2 group and the 225 cows from VT1 group were sampled once. VT1 group from the Virginia Tech dairy herd, included animals from a lactating dairy herd (various lactation and days in milk) as well as pregnant heifers.

Library preparation and computational analysis were performed as previously described $[14,23]$. Briefly, serum pools were filtered through a $0.45-\mu \mathrm{m}$ filter (Millipore) to remove eukaryotic- and bacterial cell-sized particles, and $330 \mu \mathrm{L}$ of each pool was then subjected to a mixture of nuclease enzymes to reduce the concentration of free (non-viral encapsidated) nucleic acids [23]. Viral 
nucleic acids were then extracted (MagMAX Viral RNA Isolation Kit, Ambion, Inc, Austin, Tx, USA) and random RT-PCR was used to amplify RNA and DNA. Four libraries were constructed using Nextera XT DNA Sample Preparation Kit (Illumina) and sequenced using the Miseq Illumina platform with 250 bases paired ends with dual barcoding for each pool.

\section{Results}

Four serum pools from a total of 715 animals were enriched for viral nucleic acids which were then randomly amplified and deep sequenced on the Ilumina platform. Out of $\sim 47.4$ million sequence reads, $\sim 1 \%(44,279)$ were found by BLASTx to contain open reading frames encoding for parvovirus related proteins (BLASTx E scores $<10^{-5}$ ). Two complete coding regions of parvovirus genomes could be assembled. Bovine parvovirus 2 (BPV2 in the ungulate copiparvovirus 1 species) was detected and its genome assembled (GenBank accession number KY019140). BPV2's nonstructural (NS) and VP1 proteins showed $94-96$ and $89-96 \%$ identity to the 3 BPV2 genomes currently available in GenBank database. BPV2 sequences were detected in three pools (Table 1). The second parvovirus genome was more divergent relative to known viral genomes showing its closest relative to be porcine parvovirus 6 (PPV6 in the ungulate copiparvovirus 2 species) with 40\% amino acid identity in their non-structural protein. The virus was named bosavirus (Bovine serum associated virus and genome sequence deposited as GenBank accession number KY019139). Phylogenetic analyses showed bosavirus' NS clustering with the NS of copiparvoviruses (Fig. 1). The bosavirus VP was slightly more closely related to the VP of the recently described sesavirus (36\% identity) from a sea lion than to that of PPV6 (34\% identity) (Fig. 2). Bosavirus sequences could be detected in all four pools (Table 1). According to a proposal from the International Committee on Taxonomy of Viruses (ICTV), members of the same parvovirus genus should share $>30 \%$ identity in NS1 while members of the same species should exhibit $>85 \%$ identity in NS1 [8]. Based on pair-wise NS1 alignments, bosavirus is therefore proposed as member of a new species in the Copiparvovirus genus (ungulate copiparvovirus 3 ).

Using the bosavirus and the BPV2 genomes described above and the program Genious (Genious R6, 5.6.3 software with default settings) we calculated that $98.21 \%$ of the parvovirus-like sequences could be matched to the bosavirus genome and $1.28 \%$ to BPV2 genome. Therefore $99.5 \%$ of parvovirus-related protein sequences detected here belonged to these two parvovirus species. The remaining parvovirus related reads consisted of mutated BPV2 and bosavirus reads (likely due to sequencing errors), chimeric reads that were only partly BPV2 or bosavirus, and five reads in GA2 pool that matched (>95\% nucleotide similarity) porcine hokovirus (GenBank EU200677) [13] in the ungulate tetraparvovirus 2 species
[8].

Other viral sequences were also detected but in much smaller numbers. Five sequence reads showing 97-100\% amino acid sequence identity to the RNA genome of bovine hepacivirus, a recently described member in the Hepacivirus genus of the Flaviviridae family (GenBank: KP265948.1) [7,21], were detected in GA2 pool. Bovine hepacivirus RNA has been detected in 1.6\% of individually tested cows and in 3.8\% of tested herds in Germany where its tissue distribution indicated possible liver tropism but no clear association with disease has been established [2]. Also detected were 4 papillomavirus reads. The GA2 pool yielded one read that was $100 \%$ identical to human betapapillomavirus HPVX14 (GenBank: AF054874.1). Pool IA2 yielded three papillomavirus reads. One was $91 \%$ identical to the unclassified human papillomavirus type 174 (GenBank: HF930491.1), one 98\% identical to human betapapillomavirus RTRX7 (GenBank: U85660.1) and one 96\% identical to human betapapillomavirus type 151 (GenBank: FN677756.1).

\section{Discussion}

Our analysis characterizing enriched viral sequences in calf serum showed that parvovirus sequences dominated relative to other viruses (Table 1). As bovine fetuses acquire their viral infections from pregnant cows the potential exist for the viruses described here to also infect fetuses. The detection of a previously uncharacterized parvovirus (bosavirus) present in each US serum pool analyzed indicates that its presence and infectivity should be considered when testing fetal bovine serum for viral contamination. To date, members of the Copiparvovirus genus (classified based on NS) have only been reported in bovine or porcine samples [8]. Whether only ungulates can be infected by copiparvoviruses, therefore posing little risk of infection to non-ungulate mammals, will become clearer as more parvoviruses are described in additional mammalian species. While bosavirus can be classified as a copiparvovirus based on its NS, its VP was more closely related to that of a parvovirus from the feces of a carnivore (Zalophus californianus or California sea lion) whose NS sequence falls outside the range of copiparvoviruses [19]. The tropism of bosavirus may therefore extend beyond that of the currently known copiparvoviruses so far described only in ungulate samples. A few reads of porcine hokovirus, classified in the Tetraparvovirus genus, were also detected in one pool indicating that this virus, previously reported in porcine samples, may also infect calves albeit at low level relative to bosavirus and BPV2 (Table 1).

A low number of bovine hepacivirus (Flaviviridae family), a virus originally detected in African cattle and then herds in Germany, were also detected in one pool [2,7]. Whether this hepacivirus can be transmitted to bovine fetuses or is capable of infecting other

Table 1

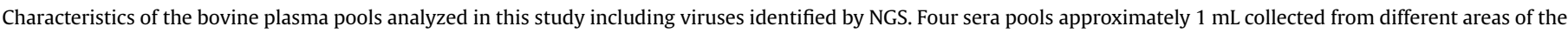
United States were applied for NGS.

\begin{tabular}{|c|c|c|c|c|c|}
\hline Pool & Animal number & Age & Age at Sampling & States of origin & Virus detected (Reads) \\
\hline GA1 & 25 calves & $3-240$ days & $3,30,60,120,200,240$ & GA & 1. Bosavirus $(30,590)$ \\
\hline GA2 & 90 calves & $3-240$ days & $3,30,60,120,200,240$ & GA & $\begin{array}{l}\text { 1. Bosavirus }(1,931) \\
\text { 2. Bovine parvovirus } 2(286) \\
\text { 3. Bovine hepacivirus }(5) \\
\text { 4. Human papillomavirus (4) }\end{array}$ \\
\hline IA2 & 375 calves & Unknown & Unknown & IA, NE, SD, NM, OK, TX, SD, ND, WY, MT. & $\begin{array}{l}\text { 1. Bosavirus }(9,980) \\
\text { 2. Bovine parvovirus } 2(106) \\
\text { 3. Human papillomavirus (3) }\end{array}$ \\
\hline VT1 & 225 cows & Unknown & All ages and all stages of lactation & VT & $\begin{array}{l}\text { 1. Bosavirus (989) } \\
\text { 2. Bovine parvovirus } 2 \text { (184) }\end{array}$ \\
\hline
\end{tabular}




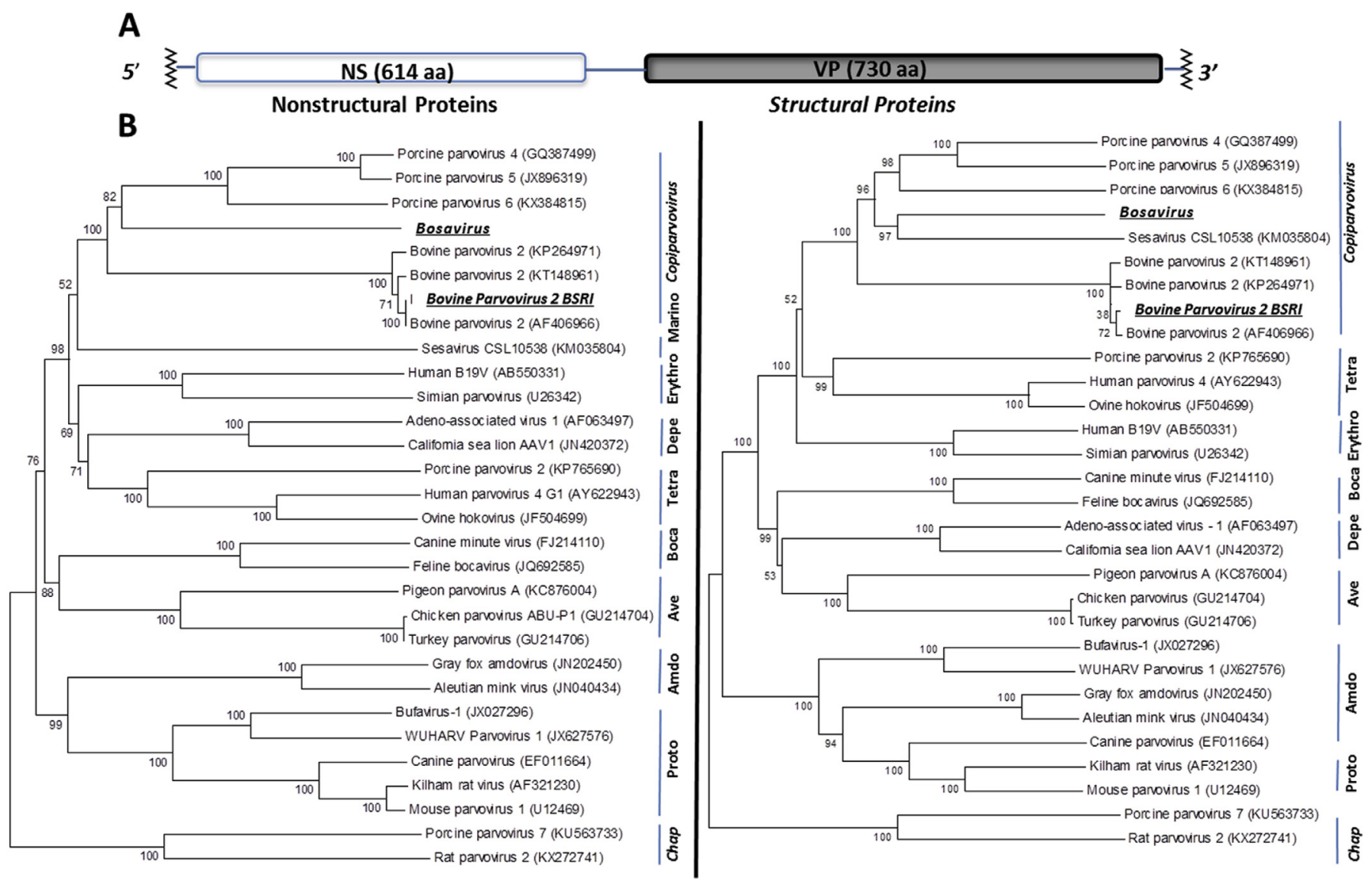

Fig. 1. Genome structure of bosavirus reported in this study (A). Maximum likelihood phylogenies show the relationship of the novel Bosavirus and BPV2 (B) to representatives of genera in the subfamily Parvovirinae.

\begin{tabular}{|c|c|c|c|c|c|c|c|c|}
\hline & & \multicolumn{7}{|c|}{ NS } \\
\hline & & 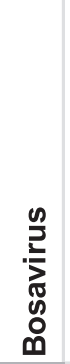 & 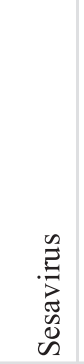 & 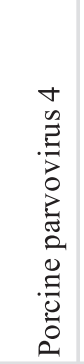 & 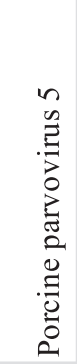 & 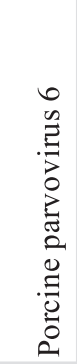 & 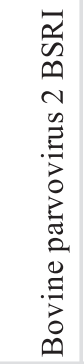 & 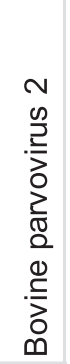 \\
\hline \multirow{7}{*}{ VP } & Bosavirus & 100 & 22.9 & 32.4 & 32.6 & 40 & 30.3 & 30 \\
\hline & Sesavirus CSL10538 (KM035804) & 36 & 100 & 24.9 & 25.5 & 25.2 & 25.3 & 25 \\
\hline & Porcine parvovirus 4 (GQ387499) & 32 & 32.9 & 100 & 86.1 & 53.1 & 33.4 & 33 \\
\hline & Porcine parvovirus 5 (JX896319) & 27 & 25.2 & 53.2 & 100 & 51.9 & 33 & 33 \\
\hline & Porcine parvovirus 6 (KX384815) & 34 & 22.6 & 38.6 & 30.6 & 100 & 30.8 & 31 \\
\hline & Bovine parvovirus 2 BSRI 2016 & 24 & 23.1 & 29.8 & 25.8 & 20.2 & 100 & 93 \\
\hline & Bovine parvovirus 2 (AF406966) & 24 & 23.2 & 29.8 & 25.8 & 20.2 & 96.1 & 100 \\
\hline
\end{tabular}

Fig. 2. VP and NS amino acid sequences identities between Bosavirus and Copiparvoviruses. The lower-left triangle shows homology between VP1 protein sequences of the six Copiparvoviruses generated by ClustalW alignment using Geneious Pro 6.1.8 software with default settings. The upper-right triangle shows NS amino acid sequence identities against of the six Copiparvoviruses.

species is not known. Another member of the Flaviviridae family, bovine viral diarrhea virus classified in a different genus (Pestivirus) was not detected in our study. The absence of BVDV detection may be due to the high rate of BVDV vaccination in US herds and low rate of persistent viremia [9,22]. The papillomavirus sequences detected were closely related to viruses detected in human skin. Whether these sequences reflect contamination with human skin or bovine papillomaviruses possibly introduced into the serum 
pools from calve skin during phlebotomy is also unknown $[4,18]$.

The vast majority of viral reads therefore originated from BPV2 and bosavirus whose infectivity to other mammal species is unknown. Parvoviruses are particularly difficult to remove by filtration, due to small capsid sizes of $20-30 \mathrm{~nm}[5,11,12]$. Based on viral particle size, the $100 \mathrm{~nm}$ pore filtration step used in the manufacture of fetal bovine serum is not expected to completely remove parvoviruses. The small ssDNA genomes of $\sim 5 \mathrm{~Kb}$ may also make parvoviruses particularly resistant to different viral nucleic acid inactivation methods $[5,11,12]$. The FDA mandated testing for the detection of extraneous viruses (9 CFR 111.47) includes serological tests for parvovirus antigens of bovine parvovirus (Bocaparvovirus genus), canine parvovirus (Protoparvovirus genus), feline panleukopenia virus (Protoparvovirus genus), and porcine parvovirus (Protoparvovirus genus), following cell culture infections. Based on the high degree of genetic divergence of these parvoviruses to BPV2 and bosavirus (both in Copiparvovirus genus) strong serological cross reactivity is unlikely.

\section{Acknowledgement}

We acknowledge NHLBI grant R01 HL105770 to E.D, and the Blood Systems Research Institute. Mohammadreza Sadeghi was supported by The Sigrid Jusélius Foundation (grant WBS 4703764).

\section{References}

[1] Allander T, Emerson SU, Engle RE, Purcell RH, Bukh J. A virus discovery method incorporating DNase treatment and its application to the identification of two bovine parvovirus species. Proc Natl Acad Sci U. S. A 2001;98: 11609-14.

[2] Baechlein C, Fischer N, Grundhoff A, Alawi M, Indenbirken D, Postel A, et al Identification of a novel hepacivirus in domestic cattle from Germany. J Virol 2015;89:7007-15.

[3] Bauermann FV, Ridpath JF, Weiblen R, Flores EF. HoBi-like viruses: an emerging group of pestiviruses. J Vet Diagnos Investig Off Publ Am Assoc Vet Lab. Diagnos Inc 2013;25:6-15.

[4] Buchta C, Nedorost N, Regele H, Egerbacher M, Kormoczi G, Hocker P, et al. Skin plugs in phlebotomy puncture for blood donation. Wien Klin Wochenschr 2005; 117:141-4.

[5] Caballero S, Diez JM, Belda FJ, Otegui M, Herring S, Roth NJ, et al. Robustness of nanofiltration for increasing the viral safety margin of biological products. Biol J Int Assoc Biol Stand 2014;42:79-85.

[6] Chen D, Nims R, Dusing S, Miller P, Luo W, Quertinmont M, et al. Root cause investigation of a viral contamination incident occurred during master cell bank (MCB) testing and characterization-a case study. Biol J Int Assoc Biol Stand 2008;36:393-402.

[7] Corman VM, Grundhoff A, Baechlein C, Fischer N, Gmyl A, Wollny R, et al. Highly divergent hepaciviruses from African cattle. J Virol 2015;89:5876-82.

[8] Cotmore SF, Agbandje-McKenna M, Chiorini JA, Mukha DV, Pintel DJ, Qiu J, et al. The family parvoviridae. Arch Virol 2014;159:1239-47.

[9] Fulton RW, Whitley EM, Johnson BJ, Ridpath JF, Kapil S, Burge LJ, et al. Prevalence of bovine viral diarrhea virus (BVDV) in persistently infected cattle and BVDV subtypes in affected cattle in beef herds in south central United States. Can J Vet Res = Revue Can de Recherche Vet 2009;73:283-91.

[10] Gagnieur L, Cheval J, Gratigny M, Hebert C, Muth E, Dumarest M, et al. Unbiased analysis by high throughput sequencing of the viral diversity in fetal bovine serum and trypsin used in cell culture. Biol J Int Assoc Biol Stand 2014; $42: 145-52$.

[11] Gefroh E, Dehghani H, McClure M, Connell-Crowley L, Vedantham G. Use of MMV as a single worst-case model virus in viral filter validation studies. PDA J Pharm Sci Technol 2014;68:297-311.

[12] Kwon SY, Kim IS, Bae JE, Kang JW, Cho YJ, Cho NS, et al. Pathogen inactivation efficacy of Mirasol PRT System and Intercept Blood System for nonleucoreduced platelet-rich plasma-derived platelets suspended in plasma. Vox Sang 2014;107:254-60.

[13] Lau SK, Woo PC, Tse H, Fu CT, Au WK, Chen XC, et al. Identification of novel porcine and bovine parvoviruses closely related to human parvovirus 4. J Gen Virol. 2008;89:1840-8.

[14] Li L, Deng X, Mee ET, Collot-Teixeira S, Anderson R, Schepelmann S, et al. Comparing viral metagenomics methods using a highly multiplexed human viral pathogens reagent. J Virol Methods 2015;213:139-46.

[15] Marcus-Sekura C, Richardson JC, Harston RK, Sane N, Sheets RL. Evaluation of the human host range of bovine and porcine viruses that may contaminate bovine serum and porcine trypsin used in the manufacture of biological products. Biol J Int Assoc Biol Stand 2011;39:359-69.

[16] Nairn C, Lovatt A, Galbraith DN. Detection of infectious bovine polyomavirus. Biol J Int Assoc Biol Stand 2003;31:303-6.

[17] Nims RW. Detection of adventitious viruses in biologicals-a rare occurrence. Dev Biol 2006;123:153-64. discussion 183-197.

[18] Patton RG, Schmitt T. Innovation for reducing blood culture contamination: initial specimen diversion technique. J Clin Microbiol 2010;48:4501-3.

[19] Phan TG, Gulland F, Simeone C, Deng X, Delwart E. Sesavirus: prototype of a new parvovirus genus in feces of a sea lion. Virus Genes 2015;50:134-6.

[20] Pinheiro de Oliveira TF, Fonseca Jr AA, Camargos MF, de Oliveira AM, Pinto Cottorello AC, Souza Ados R, et al. Detection of contaminants in cell cultures, sera and trypsin. Biol J Int Assoc Biol Stand 2013;41:407-14.

[21] Smith DB, Becher P, Bukh J, Gould EA, Meyers G, Monath T, et al. Proposed update to the taxonomy of the genera Hepacivirus and Pegivirus within the Flaviviridae family. J Gen Virol 2016 Nov;97:2894-907.

[22] Wittum TE, Grotelueschen DM, Brock KV, Kvasnicka WG, Floyd JG, Kelling CL, et al. Persistent bovine viral diarrhoea virus infection in US beef herds. Prev Vet Med 2001;49:83-94.

[23] Zhang W, Li L, Deng X, Blumel J, Nubling CM, Hunfeld A, et al. Viral nucleic acids in human plasma pools. Transfusion 2016;56:2248-55. 